\title{
Expression of concern: Co-receptor CD8-mediated modulation of T-cell receptor functional sensitivity and epitope recognition degeneracy
}

\section{Frontiers in Immunology Editorial Office*}

Frontiers in Immunology Editorial Office, Frontiers, Lausanne, Switzerland

*Correspondence: immunology.editorial.office@frontiersin.org

Co-receptor CD8-mediated modulation of T-cell receptor functional sensitivity and epitope recognition degeneracy

by Szomolay B, Williams T, Wooldridge $L$ and van den Berg HA. Front Immunol (2013) 4:329. doi:10.3389/fimmu.2013.

00329

\section{EXPRESSION OF CONCERN}

The Editorial Board has been informed by the authors of "Co-receptor CD8mediated modulation of $\mathrm{T}$-cell receptor functional sensitivity and epitope recognition degeneracy" that the parameter values as reported in the legends are mutually inconsistent and therefore the results of the simulations have to be reconfirmed. This is to notify readers that the data as published in the original article are not validated and that the authors have stated to the Editorial Board that a Corrigendum is in preparation.

Received: 06 August 2014; accepted: 06 August 2014; published online: 18 August 2014.
Citation: Frontiers in Immunology Editorial Office (2014) Expression of concern: Co-receptor CD8mediated modulation of $T$-cell receptor functional sensitivity and epitope recognition degeneracy. Front. Immunol. 5:401. doi:10.3389/fimmu.2014.00401

This article was submitted to T Cell Biology, a section of the journal Frontiers in Immunology.

Copyright (c) 2014 Frontiers in Immunology Editorial Office. This is an open-access article distributed under the terms of the Creative Commons Attribution License (CC BY). The use, distribution or reproduction in other forums is permitted, provided the original author(s) or licensor are credited and that the original publication in this journal is cited, in accordance with accepted academic practice. No use, distribution or reproduction is permitted which does not comply with these terms. 